日本水迹會誌第十三第一栫昭和二十二年四月

\title{
鯨皮脂肪層の化學的研究 ※
}

\section{第 1 報 脂 肪 $の$ 分 布}

山田紀作

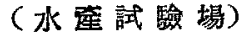

鲸皮脂肪層は以前から探油の原料として重悓せ放れて柬たが,現今では皮革の原料としたク，又食用と

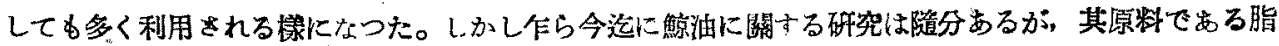

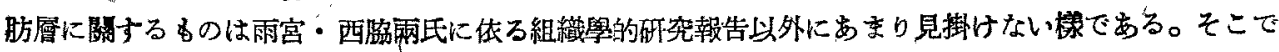

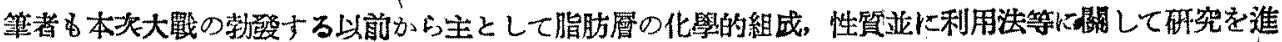
めてるたのであるが，戰況の進展すると共に原料難其他の篇一時中絕せざるを得なくなり現在に至つた が，幸にしてヌるや昔の華かた捕鯨の侍代を再現せんとしてるるので, 試驗結果の一部概要を以下に記 して見ることにしたが何かの若筫料となれば幸甚である。

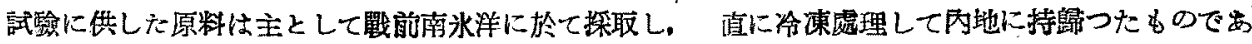

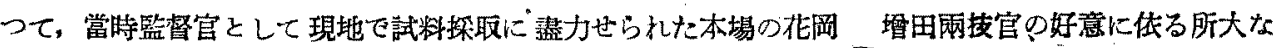

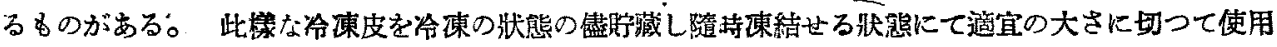
した。先一第一に脂肪の分右狀態を調へる罵に一番表面の黑皮郎表皮の部分をきれいに切取つてから真 坡と表皮との堺面を零點とし，堺面郎銀面に莗直の方向に一㯵宛の間隔を計つて銀面と平行に脂肪層の 厚さに應し任意の數大切取り，各一定量宛を秤量して其中に含む水分蛋白（微量の無機物を含む）及脂 助を夫及常法に㑈り定量分柝した。其結果仕第 1 表乃至第4 表に示す通りである。層位には試料とした

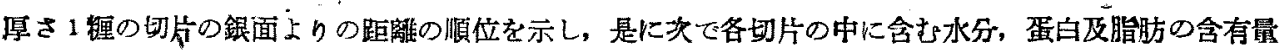
百分比る示してむる。此秥果に依つて見ると明かな栐に各種の鯨によつて脂肪層中に於ける脂肪の分布

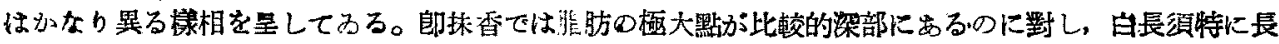
須では銀面に近い所にある。又座頚の如きすのは上上の三とは全く趣を異にし，層の何れの部位す殆ん

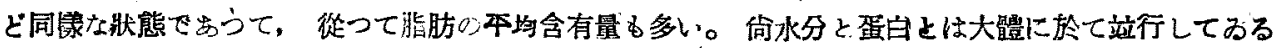
が, 此兩者と脂肪とは殆んど對蹠的てある。

以上の數字は一定央量の試料郎 100 瓦中の各組成分 の重量を示してみるので出るか，各切片の脂肪含有量 の異ろ結果比重が同しでないから一定容積の各噟を比 较して考一る時には酸合しない。今脂肪層の研究を行

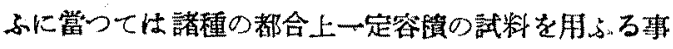
が多いので，先づ等層の切片について各ぬの比重を計 つて見ると第 5 表の椂な数値を得たので是上り前記分 析檤を換算して各屏 $100 \mathrm{cc}$ 中の各組成分含有量老圆示 したすのが，第 1 圆乃至第 4 圆である。主軸に各切片 の銀面よりの距離の順位を示し縱軸儿は各組成分の含 有量を示しておる。

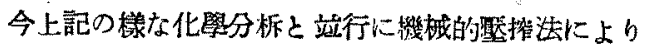
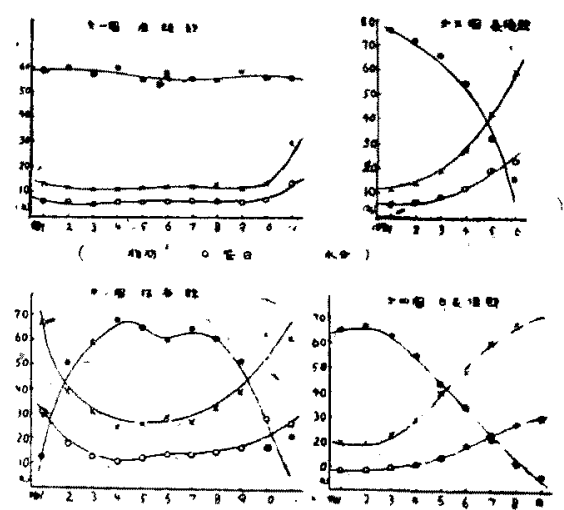

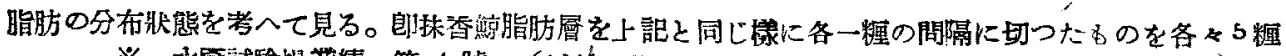
※ 水窐試驗賜業㺓 第 4 號 $(1946-47)$ 


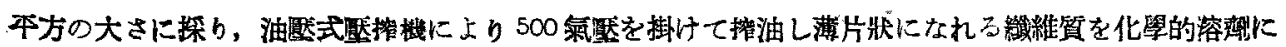

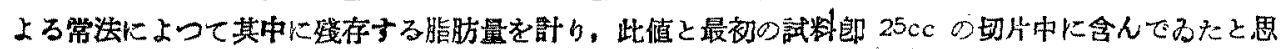

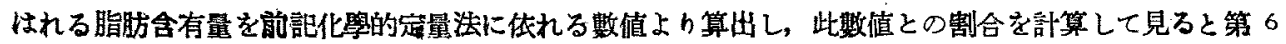

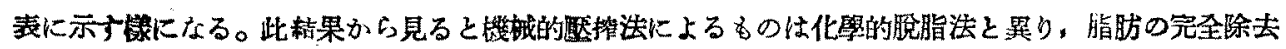
は不可能な事は當然ではあるが，層位によるて线存する脂肪の全脂肪量に對する割合がかなり罢つてる

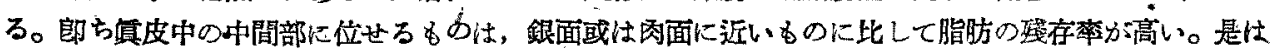
單に其部位に於ける脂肪の含有量が多いと云ふ詰りでなく，脂肪の含有してるる狀態が異つてるるから

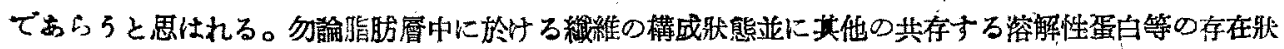
態が各層位に伡つて異るのでるるから, 必然的に脂肪の共存する狀態が異つてる不思議はないと推测さ れるが, 此事については倘多くの研究を必要とするのて詳しい事情後報讓ることにする。何最後に本

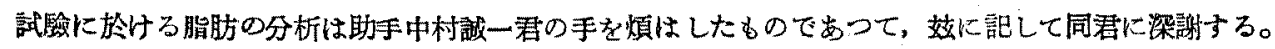

第 1 表，抹香鯨脂肪噟組成

\begin{tabular}{|c|c|c|c|}
\hline 層 位 & 水 & 蛋 白 & 脂 \\
\hline 1 & 60.1 & 28.7 & 11.2 \\
\hline 2 & 36.2 & 16.5 & 47.3 \\
\hline 3 & 30.1 & 12.2 & 57.7 \\
\hline 4 & 24.3 & 10.5 & 65.2 \\
\hline 5 & 250 & 12.1 & 629 \\
\hline 6 & 28.2 & 13.6 & 58.2 \\
\hline 7 & 25.6 & 13.0 & 61.4 \\
\hline 8 & 30.1 & 13.9 & 56.0 \\
\hline 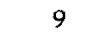 & 36.6 & 15.4 & 48.0 \\
\hline 10 & 57.2 & 27.0 & 15.8 \\
\hline 11 & 55.3 & 24.7 & 20.0 \\
\hline
\end{tabular}

第 3 表 長須鯨脂肪虞組成

\begin{tabular}{|c|c|c|c|}
\hline 願 位 & 水 & 蛋 百 & 宿 \\
\hline 1 & 13.0 & 6.2 & 80.8 \\
\hline 2 & 15.6 & 7.6 & 76.8 \\
\hline 3 & 21.1 & 9.1 & 69.9 \\
\hline 4 & 29.0 & 13.7 & 57.3 \\
\hline 5 & 452 & 20.9 & 33.9 \\
\hline 6 & 59.1 & 24.4 & 16.6 \\
\hline
\end{tabular}

第 5 表 各種鯨皮脂肪層の各層伦。 注於汀此重

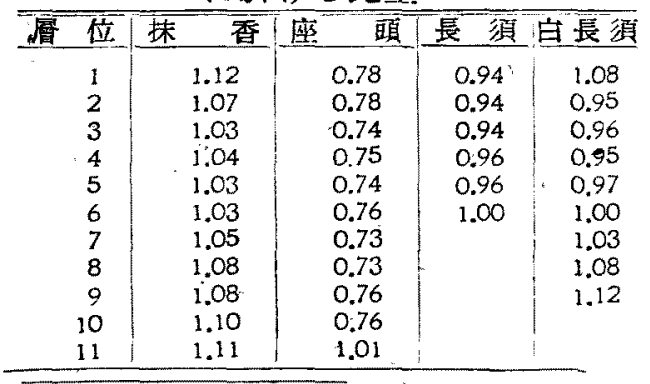

第 2 表 夾頭䑸脂肪層組成

\begin{tabular}{|c|c|c|c|}
\hline 磨 位 & 水 & 蛋 & 脂。 \\
\hline 1 & 16.0 & 8.1 & 75.1 \\
\hline 2 & 15.5 & 7.2 & 76.3 \\
\hline 3 & 14.5 & 7.2 & 77.3 \\
\hline 4 & 14.0 & 6.7 & 79.3 \\
\hline 5 & 15.8 & 6.8 & 77.4 \\
\hline 6 & 15.5 & 7.6 & 76.9 \\
\hline 7 & 16.5 & 7.6 & 75.9 \\
\hline 8 & 17.5 & 7.6 & 74.9 \\
\hline 9 & 14.5 & 7.4 & 78.1 \\
\hline 10 & 17.5 & 8.5 & 74.0 \\
\hline 11 & 30.0 & 14.2 & 55.8 \\
\hline
\end{tabular}

第 4 表 日長須鯨脂肪廜組成

\begin{tabular}{|c|c|c|c|}
\hline 覻 位 & 水 分 & 蛋 白 & 诣 \\
\hline 1 & 21.5 & 9.9 & 68.6 \\
\hline 2 & 20.5 & 9.7 & 69.8 \\
\hline 3 & 24.0 & 10.3 & 65.7 \\
\hline 4 & 30.1 & 11.8 & 58.1 \\
\hline 5 & 40.0 & 14.2 & 458 \\
\hline 6 & 46.8 & 18.6 & 34.6 \\
\hline 7 & 559 & 22.5 & 21.6 \\
\hline 8 & 63.0 & 25.8 & 11.2 \\
\hline 9 & 63.6 & 29.5 & 6.9 \\
\hline
\end{tabular}

第6 表 機棫的厴控法に依る脂肪層各 層位に於ける脂肪の殘存割合 $(\%)$

\begin{tabular}{l|ll|l|l|l|l|l|l|l}
\hline 層位 & 1 & 2 & 3 & 4 & 5 & 6 & 7 & 8 & 9 \\
\hline 佂存 & 2.2 & 2.9 & 2.6 & 5.7 & 6.6 & 2.9 & 3.2 & 1.4 & 1.2 \\
\hline
\end{tabular}

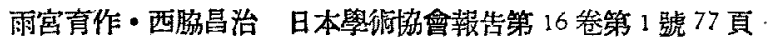

